\title{
ІНФОРМАЦІЙНІ АСПЕКТИ ОБҐРУНТУВАННЯ СТРУКТУРНИХ СКЛАДОВИХ БЕЗПЕКИ ПАЦІЄНТА
}

Л. Ю. Бабінцева

\author{
Національна медична академія післядипломної освіти імені П. Л. Шупика
}

\begin{abstract}
Розглянуто питання безпечності надання медичної допомоги. Формалізовано термінологічну базу проблеми. Запропонована трирівнева структура забезпечення безпеки пацієнта: якісне надання медичної допомоги; організація дій при нестандартних ситуаціях; забезпечення індивідуального підходу до ведення пацієнта.
\end{abstract}

Ключові слова: безпека пацієнта, інформація, якість медичної допомоги, лікарські засоби, фармацевтична опіка, трирівнева структура забезпечення безпеки пацієнта.

\section{ИНФОРМАЦИОННЫЕ АСПЕКТЫ ОБОСНОВАНИЯ СТРУКТУРНЫХ СОСТАВЛЯЮЩИХ БЕЗОПАСНОСТИ ПАЦИЕНТА}

Л. Ю. Бабинцева

Национальная медицинская академия последипломного образования имени П. Л. Шупика

Рассмотрены вопросы безопасности оказания медицинской помощи. Формализована терминологическая база проблемы. Предложена трехуровневая структура обеспечения безопасности пациента: качественное предоставление медицинской помощи; организация действий при нестандартных ситуациях; обеспечение индивидуального подхода к ведению пациента.

Ключевые слова: безопасность пациента, информация, качество медицинской помощи, лекарственные средства, фармацевтическая опека, трехуровневая структура обеспечения безопасности пациента.

\section{BACKGROUND INFORMATION ASPECTS OF STRUCTURAL COMPONENTS PATIENT SAFETY}

\section{Shupyk National Medical Academy of Postgraduate Education}

There was discussed the question of the safety of medical care. It was formalized terminology database problems and proposed three-tier structure to ensure patient safety: quality of medical care; the organization action in unusual situations; an individual approach to the management the patient care.

Key words: patient safety, information, quality of care, pharmaceuticals, pharmaceutical care, three-tier structure for the safety of the patient.

Вступ. На 58 сесії Всесвітньої асамблеї охорони здоров'я прийнято резолюцію WHA58.28 щодо електронної охорони здоров'я (eHealth). 3 того часу інформаційно-комунікаційні технології зайняли центральне місце в забезпеченні безпеки здоров'я, наданні медико-санітарної допомоги, перебудові систем охорони здоров'я в світі. Держави-члени також закликали до розроблення інфраструктури інформаційно-комунікаційних технологій в інтересах здоров'я, продовженні роботи з інформацій- ними, телекомунікаційними установами та іншими партнерами [1].

За визначенням ВОО3, «якісне медичне обслуговування - це обслуговування, при якому ресурси організуються таким чином, щоб із максимальною ефективністю та безпечністю задовольняти медико-санітарні потреби тих, хто найбільше потребує допомоги, проводити профілактику та лікування без непотрібних витрат і відповідно до вимог найвищого рівня» [2]. 
На наш погляд, ключовою складовою визначення слід вважати безпечність надання медичної допомоги. Взагалі, забезпечення безпеки пацієнта - одна 3 актуальних проблем медицини та фармації, що має особливе значення для глобальної охорони здоров'я.

Розглядаючи аналітичний процес зі зниження рівня небезпеки як від медичних, так і від фармацевтичних дій можна сказати, що він складається 3 чотирьох основних частин: формалізації завдань, термінів, класифікацій; стратегічних питань оцінювання якості медичної допомоги; оцінювання ризиків ускладнень у процесі лікування, їх моніторингу, ідентифікації небезпеки; виявлення й аналізу помилок у діагностиці та лікуванні пацієнтів [3].

Також важливим завданням залишається формулювання стратегії забезпечення безпеки пацієнтів у сучасних умовах профілактики захворювань, діагностики, лікування та їх фармацевтичного забезпечення.

Мета роботи: запропонувати інформаційні аспекти для обгрунтування структурних складових безпеки пацієнта в сучасних умовах системи охорони здоров'я.

Матеріал та методи дослідження. Застосовували різні типи та методи контент-аналізу; методи ретроспективного та трендового аналізів; експертних оцінок (задіяні 14 експертів). Дослідили тренди показників захворюваності на соціально значущі хвороби [4].

Результати та їх обговорення. Формалізуємо спочатку терміни, що використані в роботі.

Під безпекою пацієнтів розуміли максимально можливу відповідність клінічних результатів наявним даним про ефективність надання медичної допомоги, очікуванням лікаря та пацієнта при мінімальному ризику небажаних наслідків (ускладнень) [3].

Під ускладненнями при медичному втручанні розуміли будь-яке погіршення стану хворого на етапах лікування: ускладнення після медикаментозної терапії, медичних маніпуляцій, діагностичних і параклінічних лікувальних втручань і ускладнення основного захворювання, що розвинулися після початку лікування в стаціонарі [6].

Психологічні конфлікти розглядаються як ті, що розвинулися безпосередньо між пацієнтом i лікарем, хворим і середнім медичним працівником тощо [7].

Під кількісною оцінкою «незадоволення пацієнтів» розуміли частку хворих, які негативно характеризують хоча б одну зі сторін лікувальнодіагностичний процесу. При цьому до уваги брали незадоволення пацієнта доступністю, перебігом або результатом лікувально-діагностичного процесу [6]. Зауважимо, що «незадоволення пацієнта» дуже часто проявляється в стаціонарах при використанні нових технологій. Так, наприклад, у клініці застосування методів екстракорпорального запліднення проблема нерозуміння основних труднощів і ризиків часто призводить до незадоволення пацієнта.

Запропонована трирівнева структура щодо забезпечення безпеки пацієнта. На вищий щабель винесено якість надання медичної допомоги.

Європейське бюро ВООЗ у звіті, присвяченому формуванню принципів забезпечення якості медичної допомоги, вказало на необхідність при вирішенні даної проблеми враховувати чотири елементи [8, 9]: кваліфікацію спеціаліста, оптимальність використання ресурсів, ризик для пацієнта, задоволеність пацієнта взаємодією 3 медичною підсистемою.

До основи сучасних європейських принципів забезпечення якості покладено такі поняття: ефективність, раціональність, справедливість і вчасність надання медичної допомоги, котрі базуються на центральній ролі пацієнта в забезпечені його безпеки та можливості отримання медичної допомоги в необхідному обсязі та належної якості.

Наступним важливим фактором гарантування безпеки надання медичної допомоги є забезпечення пацієнта необхідними та ефективними лікарськими засобами (ЛЗ). На основі експертного оцінювання виявлено умови для виникнення ризикової діяльності, як результат ігнорування логістичного підходу до управління потоковими процесами фармацевтичних товарів (послуг), низька компетентність провізорів. Менш ніж $20 \%$ керівників закладів охорони здоров'я (3О3) при прийнятті рішень щодо вибору Л3 враховують фінансову, маркетингову та, особливо, логістичну інформацію.

Розглядаючи фактор забезпеченості ЛЗ слід пам'ятати про фармацевтичну опіку, ключовими моментами якої є відповідальне надання лікарської терапії з метою досягнення конкретних результатів, що поліпшать якість життя пацієнта; взаємодія між пацієнтом і фахівцями охорони здоров'я щодо планування, здійснення та моніторингу терапевтичного плану; взаємовигідний обмін, у процесі якого пацієнт передає повноваження, а провізор приймає відповідальність від пацієнта. 
Роль провізора у безпеці в галузі охорони здоров'я представлена в Резолюції ResAP (2001) 2 Європейського Директорату 3 якості ліків та Охорони здоров'я (EDQM), де також наголошено, що фармацевтична опіка - це основний елемент у запобіганні та зниженні ятрогенних ризиків. Вона включає: ведення фармацевтичних записівспостережень, моніторинг призначень, оцінювання лікарської терапії пацієнта, раціоналізацію консультацій для пацієнта, систематичний обмін інформацією (мережа фахівців у сфері охорони здоров'я) та інформаційні технології 3 відповідними базами даних.

Отже, вагому цінність має якість надання медичної допомоги, безпосередньо пов'язаної зі станом ринку, наявністю або відсутністю конкретного ЛЗ. Саме це робить завдання управління ризиками фармацевтичного ринку складним.

Поділяючи фактори ризику на зовнішні та внутрішні, виділимо такі:

1. Зовнішні фактори ризику: економічні, політичні, соціальні, екологічні, правові, інноваційні.

2. Внутрішні фактори ризику, пов'язані з функціонуванням фармацевтичного ринку як такого: ділова активність, наявність оптимальних маркетингових стратегій, політики, тактики, а також показники: виробничий потенціал галузі, технічне оснащення, рівень спеціалізованості, рівень продуктивності праці, рівень дотримання стандартів виробництва тощо.

Другий рівень віддзеркалює організацію дій при виникненні нестандартних ситуацій у лікуванні пацієнтів.

Для визначення структури факторів при інцидентах у діагностиці та лікуванні пацієнтів про- понується використання міжнародної класифікації безпеки пацієнтів (International Classification of Patient Safety - ICPS), відповідно до якої виділяють 10 рівнів (вищих пріоритетів): 1. Тип інциденту. 2. Результат лікування пацієнта. 3. Характеристики пацієнта. 4. Характеристики інциденту. 5. Діючі чинники / ризики. 6. Організаційні висновки. 7. Детекція (розслідування). 8. Чинники поліпшення. 9. Дії з поліпшення стану. 10. Зроблені дії зі зменшення ризику [10].

Класифікація наступного рівня містить 48 основних (ключових) концептів. Вони визначені та виділені як переважні терміни для поліпшення розуміння і передавання інформації для забезпечення безпеки пацієнта. Ці концепти представлені як стартові. Нами концептуально база ICPS розглядалася для визначення методів і підходів щодо створення системи безпеки пацієнтів.

Найскладнішою складовою забезпечення безпеки пацієнта є врахування його індивідуальних особливостей, що складає третій рівень структури системи. Саме на цьому рівні необхідним $є$ застосування інформаційних підходів. На тепер вони практично відсутні, про що свідчить значний розкид даних (не забезпечена уніфікація збору та інтерпретації даних).

Важливо підкреслити, що третій рівень об'єднує як морфологічні та фізіологічні особливості пацієнта, так і його психологічні параметри, реакції на особливості надання медичної допомоги. Ілюстрацією розбіжностей думок пацієнтів є дані таблиці 1, де проаналізовано основні складові незадоволеності. Максимальна рейтингова оцінка дорівнювала 10. Максимальне значення інформативності - 2,4.

Таблиця 1. Складові незадоволеності пацієнтів при лікуванні в стаціонарі

\begin{tabular}{|l|c|c|c|c|}
\hline \multirow{2}{*}{\multicolumn{1}{|c|}{ Складові незадоволеності }} & \multicolumn{2}{|c|}{ Рейтингова оцінка } & Інформативність & $\begin{array}{c}\text { Розмах варіювання } \\
\text { регіональних змін }\end{array}$ \\
\cline { 2 - 5 } & абс. & $\pm \mathrm{m}$ & ум. один. & 42 \\
\hline Якість надання медичної допомоги & 8,2 & 2,1 & 1,9 & 49 \\
\hline Організація роботи стаціонару & 6,4 & 2,2 & 1,8 & 38 \\
\hline Матеріально-технічне оснащення & 5,7 & 1,7 & 1,7 & 55 \\
\hline Довгий час очікування госпіталізації & 4,3 & 1,4 & 1,7 & 58 \\
\hline Недостатня якість їі & 3,7 & 1,8 & 1,3 & 36 \\
\hline Неуважність медичного персоналу & 5,1 & 2,0 & 1,8 & \\
\hline
\end{tabular}

Як можна бачити 3 таблиці 1 , найбільша інформативність виявлена саме для безпосередньої оцінки якості надання медичної допомоги. Значно менше уваги звертається на ряд інших факторів: якість 
їжі, довгий час очікування госпіталізації тощо. Але головне - відзначається досить велика дисперсія оцінок, що складає до $40 \%$.

Отже, до основних структурних складових безпеки пацієнтів у 303 віднесли: забезпечення належної медичної допомоги; виконання умов надання медичної допомоги (постачання Л3, налагодження функціонування приладів для якісної діагностики стану органів та систем пацієнта, підготовка персоналу); забезпечення індивідуального підходу до ведення пацієнта (профілактика психологічних конфліктів, облік факторів, що обумовлюють незадоволення пацієнта медичною допомогою).

Висновки. 1. Запропонована трирівнева структура забезпечення безпеки пацієнта.

2. Основними складовими безпеки пацієнта на вищому рівні $є$ висока якість надання медичної допомоги. Відповідно, ризики їі погіршення

\section{Література}

1. Режим доступу: http://apps.who.int/iris/bitstream/ 10665/20378/1/ WHA58_28-en.pdf?ua=1.

2. Бабінцева Л. Ю. Засади створення державної системи інформаційного моніторингу фармацевтичного ринку / Л. Ю. Бабінцева // Медична інформатика та інженерія. - 2012. - № 1. - С. 33-36.

3. Інформаційна платформа забезпечення безпеки пацієнтів / О. П. Мінцер, П. Мієржевський, В. Г. Сердюк [та ін.] // Медична інформатика та інженерія. - 2012.

- № 4. - С. 5-11.

4. Шиянов Б. А. Методы анализа и управления рисками в системе регулирования неравновесными состояниями экономических систем / Б. А. Шиянов, Г. Б. Шиянова // ИнВестРегион. - 2009. - № 4. - С. 23-31.

5. Концепція інформатизації охорони здоров'я України / О. П. Мінцер, Ю. В. Вороненко, Л. Ю. Бабінцева [та ін.] // Медична інформатика та інженерія. - 2012. - № 3. - С. 5-29.

6. Шикина И. Б. Пути обеспечения безопасности пациентов в многопрофильном стационарном лечебно- одночасно слугують ризиками для забезпечення безпеки пацієнта.

3. Другий рівень забезпечення безпеки пацієнта віддзеркалює організацію дій при нестандартних ситуаціях у лікуванні пацієнтів. В його обгрунтуванні важливим є застосування міжнародної класифікації безпеки пацієнтів (International Classification of Patient Safety- ICPS).

4. Третій рівень $є$ найскладнішою складовою щодо забезпечення безпеки пацієнта - це врахування індивідуальних особливостей пацієнта для профілактики ускладнень патологічного процесу, в тому числі внаслідок медикаментозного навантаження.

5. Обгрунтовано необхідність поетапного впровадження комплексної системи забезпечення безпеки пацієнтів.

профилактическом учреждении / И. Б. Шикина // Пособие для организаторов здравоохранения. - М., 2006. - 36 c.

7. Международная концепция обеспечения безопасности пациента. Аналитическое обозрение и постановка проблем для будущего / [Минцер О. П., Миержевский П., Сердюк В. Г., Денисенко С. В., Бабинцева Л. Ю.] // Зелена книга Національного плану дій з безпеки пацієнтів та матеріали Першого національного конгресу з безпеки пацієнтів. - К. : ВБО «Рада захисту прав та безпеки пацієнтів», 2012. - 298 с. - С. 134-156.

8. Assuring the quality of health care in the European Union http://www.euro.who.int/_data/assets/pdf file/0007/98233/E91397.pdf.

9. Towards an International Classification for Patient Safety: key concepts and terms / [Runciman W., Hibbert P., Thomson R. [et al.] // Int J. Qual Health Care. - 2009. № 21. - Р. 18-26.

10. Режим доступу: http://www.who.int/patientsafety/ implementation/ taxonomy/en/. 